\title{
Guidelines for antiretroviral therapy in HIV-1 infected adults and adolescents 2014, Thailand
}

\author{
Weerawat Manosuthi $i^{*}$, Sumet Ongwandee ${ }^{2}$, Sorakij Bhakeecheep ${ }^{3}$, Manoon Leechawengwongs ${ }^{4}$, Kiat Ruxrungtham ${ }^{5,6}$, \\ Praphan Phanuphak ${ }^{5,6}$, Narin Hiransuthikul ${ }^{5}$, Winai Ratanasuwan ${ }^{7}$, Ploenchan Chetchotisakd ${ }^{8}$, Woraphot Tantisiriwat ${ }^{9}$, \\ Sasisopin Kiertiburanakul ${ }^{10}$, Anchalee Avihingsanon ${ }^{6}$, Akechittra Sukkul ${ }^{11}$, Thanomsak Anekthananon ${ }^{7}$ and for The \\ Adults and Adolescents Committee of the Thai National HIV Guidelines Working Group
}

\begin{abstract}
New evidence has emerged regarding when to commence antiretroviral therapy (ART), optimal treatment regimens, management of HIV co-infection with opportunistic infections, and management of ART failure. The 2014 guidelines were developed by the collaborations of the Department of Disease Control, Ministry of Public Health $(\mathrm{MOPH})$ and the Thai AIDS Society (TAS). One of the major changes in the guidelines included recommending to initiating ART irrespective of CD4 cell count. However, it is with an emphasis that commencing HAART at CD4 cell count above $500 \mathrm{cell} / \mathrm{mm}^{3}$ is for public health, in term of preventing HIV transmission and personal benefit. In tuberculosis co-infected patients with CD4 cell counts $\leq 50$ cells $/ \mathrm{mm}^{3}$ or with CD4 cell counts $>50$ cells $/ \mathrm{mm}^{3}$ who have severe clinical disease, ART should be initiated within 2 weeks of starting tuberculosis treatment. The preferred initial ART regimen in treatment naïve patients is efavirenz combined with tenofovir and emtricitabine or lamivudine. Plasma HIV viral load assessment should be done twice a year until achieving undetectable results; and will then be monitored once a year. CD4 cell count should be monitored every 6 months until CD4 cell count $\geq 350$ cells $/ \mathrm{mm}^{3}$ and with plasma HIV viral load $<50$ copies $/ \mathrm{mL}$; then it should be monitored once a year afterward. HIV drug resistance genotypic test is indicated when plasma HIV viral load $>1,000$ copies/mL while on ART. Ritonavir-boosted lopinavir or atazanavir in combination with optimized two nucleoside-analogue reverse transcriptase inhibitors is recommended after initial ART regimen failure. Long-term ART-related safety monitoring has also been included in the guidelines.
\end{abstract}

\section{Introduction}

Combined antiretroviral therapy for the treatment of HIV infection has dramatically improved in both resource-rich and resource-constrained countries. The public health approach to scaling up antiretroviral therapy (ART) in resource-limited situation aims to support the development of treatment programs that can be accessible as widely as possible. Since 2002, the Thai Government Pharmaceutical Organization (GPO), Bangkok, Thailand, has produced GPOvir-S ${ }^{\ominus}$ which is a fixed-dose combination of stavudine (d4T), lamivudine (3TC), and nevirapine (NVP) [1-4]. The Thai GPO has launched many generic antiretroviral drugs afterward, such as tenofovir,

\footnotetext{
*Correspondence: drweerawat@hotmail.com

'Department of Medicine, Bamrasnaradura Infectious Diseases Institute, Ministry of Public Health, Tiwanon Road, Nonthaburi 11000, Thailand Full list of author information is available at the end of the article
}

efavirenz and lopinavir/ritonavir. Those generic antiretroviral drugs facilitate a drug supply procedure for the national ART program. One of the reasons is to standardize and to simplify treatment regimens and to provide drugs for treatment of drug-resistant viruses. Nowadays, more than 220,000 patients are currently treated with antiretroviral drugs under the support of the National AIDS Program (NAP) and the National Security Program. Non-nucleoside reverse transcriptase inhibitor (NNRTI)based ART remains to be the first-line recommended regimen for treatment-naive HIV-infected patients in the country to date.

The last version of Thai national guidelines for ART in HIV-1 infected adults and adolescents was published in 2010 [5]. New evidence has emerged regarding when to commence antiretroviral treatment, optimal treatment regimens, the management of HIV co-infection with 
opportunistic infections, including tuberculosis and others, as well as the management of ART failure. In 2013, WHO has launched and consolidated HIV treatment guidelines by recommending ART for HIV-patients who have CD4 cell count $\leq 500$ cells $/ \mathrm{mm}^{3}$ regardless of WHO clinical stages [6]. Nowadays, the U.S. Department of Health and Human Services (DHHS) panel and the International Antiviral Society-USA panel now recommends that ART should be offered to all HIV-infected adults $[7,8]$. Such evidences and progresses formed the basis for the new recommendations contained in the 2014 treatment guidelines and were summarized in this publication. The main consideration was based on the risks and benefits of implementing each recommendation, in addition to the acceptability, cost and feasibility. These recommendations aim to provide guidance to HIV-care providers on the appropriate use of antiretroviral drugs for the treatment of HIV infection in adults and adolescents in the country. The key updated consensus recommendations included encouraging earlier HIV treatment irrespective of CD4 cell count and promoting the use of less toxic antiretroviral regimens for the first-line ART, frequency of monitoring HIV treatment response, and drug options for the treatment-experienced patients.

The guidelines were developed by the collaborations of the Department of Disease Control, Ministry of Public Health (MOPH) and the Thai AIDS Society (TAS) The Thai National HIV Guidelines Working Group was appointed to update Thai Guidelines based on their expertise in HIV clinical research, patient care, patient insight, and government policy in Thailand. Relevant published literature and guidelines were reviewed, including clinical studies conducted in Thailand.

\section{The appropriate timing to initiate treatment}

The benefits of ART in decreasing morbidity and mortality in HIV-infected patients with low CD4 cell counts have been well established [9]. The previous national guideline recommended to initiating ART in the patients with a history of an AIDS-defining illness or CD4 cell count $<350$ cells $/ \mathrm{mm}^{3}$ [5]. To date, data supporting initiation of ART in patients with higher CD4 cell counts, ranging from 350 cells $/ \mathrm{mm}^{3}$ to $>500$ cells $/ \mathrm{mm}^{3}$, are from large observational studies and randomized controlled trials. There were a number of large cohorts showing that delaying initiation of ART until CD4 count fell below 350 cells $/ \mathrm{mm}^{3}$ was associated with a greater risk of AIDS-defining illness and/or death than initiating ART at CD4 cell count greater than 350 cells $/ \mathrm{mm}^{3}$ [10-12]. In addition, SMART, a randomized trial, demonstrated that patients who deferred ART until their CD4 cell counts dropped to $<250$ cells $/ \mathrm{mm}^{3}$ had a higher risk of AIDS- and non-AIDS-related events than those who initiated therapy immediately [13]. The study in Thais corresponded with such findings [14]. With regard to patients with CD4 cell counts $>500$ cells $/ \mathrm{mm}^{3}$, NA-ACCORD, a large observational cohort study revealed that patients who started ART with CD4 cell counts $>500$ cells $/ \mathrm{mm}^{3}$ had a higher adjusted mortality rate than those who did after their CD4 cell counts dropped below this threshold [10]. The evidences thus far showed that earlier ART initiation reduced HIV-related disease progression although the proportion of study among the patients with CD4 $>500$ cells $/ \mathrm{mm}^{3}$ remains less $[10,15]$. The benefit of ART among patients with high CD4 cell count in reducing transmission of HIV has been shown in the HPTN 052 study [16]. Given that it is placed high value on averting HIV- and AIDS-related death, disease progression and the likely risk of HIV transmission, ART is recommended for all HIV-infected patients regardless of CD4 cell count as shown in Table 1. However, the clinicians should give a priority on the patients with $\mathrm{CD} 4 \leq 500$ cells $/ \mathrm{mm}^{3}$. For patients who have CD4 > 500 cells $/ \mathrm{mm}^{3}$, the clinicians should discuss regarding their willingness and commitment to long-term treatment and their understanding the benefits and risks of the therapy and the importance of adherence. With regard to pregnant women, we recommend to initiate ART as soon as possible in all CD4 cell count levels. The goals of treatment are the same with other HIV-infected patients as well as prevention of perinatal transmission of HIV $[17,18]$.

\section{ART initiation in specific circumstances Tuberculosis co-infection}

Remarkable achievements in reducing mortality in HIV and tuberculosis (TB) co-infected patients by ART had been previously reported in Thais [19-22]. The major concern raised is that it needs to balance between mortality associated with delayed ART initiation versus mortality associated with TB-associated immune reconstitution inflammatory syndrome (TB IRIS) and/or severe overlapping

Table 1 Recommendations for antiretroviral therapy initiation in Thai HIV-infected adolescents and adults

\begin{tabular}{lc}
\hline Recommendations & Remarks \\
\hline $\begin{array}{l}\text { Recommend initiating } \\
\text { antiretroviral therapy for }\end{array}$ & In case of CD4 $>500$ cells $/ \mathrm{mm}^{3}$, taking \\
$\begin{array}{l}\text { all HIV-infected patients } \\
\text { regardless of CD4 cell }\end{array}$ & - Patients have to understand the \\
count, especially focus & benefit and side effects of treatment \\
on the patients with & as well as adhering to the regimens \\
CD4 $\leq 500$ cells $/ \mathrm{mm}^{3}$ & - Patients may decide to postpone \\
& antiretroviral therapy \\
& - Assess the readiness of the \\
& patients to start antiretroviral \\
therapy & - In case of asymptomatic \\
HIV-infected patients, the major \\
benefit is to decrease rate of HIV \\
transmission
\end{tabular}


drug hypersensitivity/toxicities with early ART. Over the past few years, six randomized trials, including one study in Thailand, had addressed how early ART should be initiated [19,23-27]. Most of the studies showed a lower mortality rate in HIV and TB co-infected patients, particularly in patients with $\mathrm{CD} 4<50$ cells $/ \mathrm{mm}^{3}$. One recent study of those with high CD4 cell count showed no difference between early and late ART on composite endpoint of death, tuberculosis treatment failure, and recurrent rate of TB [26]. It is recommended that all HIV-infected patients with active TB should be treated with ART. In patients with CD4 counts $<50$ cells $/ \mathrm{mm}^{3}$ and those with CD4 counts $\geq 50$ cells $/ \mathrm{mm}^{3}$ who have severe clinical disease, ART should be initiated within 2 weeks of starting TB treatment as shown in Table 2 . With regard to the patients with TB meningitis, however there was a higher rate of severe adverse events without clinical benefit of early ART initiation [25]. Thus, initiation of ART is at 2 weeks after TB treatment is recommended.

\section{Cryptococcosis co-infection}

Although survival benefit from ART was achieved in Thai patients co-infected HIV and cryptococcosis [28-30], optimal timing for ART initiation in patients with acute cryptococcal meningitis remains unclear. The previous published reports showed inconsistent outcomes [31,32]. A systematic review compared the clinical and immunologic outcomes for early initiation ART (less than four weeks after starting antifungal treatment) versus later initiation of ART (four weeks or more after starting antifungal treatment) in HIV-positive patients with concurrent cryptococcal meningitis [33]. There was insufficient

\begin{tabular}{|c|c|c|c|}
\hline \multirow{2}{*}{$\begin{array}{l}\text { Opportunistic } \\
\text { infections }\end{array}$} & \multirow[t]{2}{*}{$\leq 50$ cells $/ \mathrm{mm}^{3}$} & \multicolumn{2}{|l|}{$>50$ cells $/ \mathrm{mm}^{3}$} \\
\hline & & More severe* & Less severe \\
\hline Tuberculosis & Within 2 weeks & $\begin{array}{l}\text { Within } \\
2 \text { weeks }\end{array}$ & $\begin{array}{l}\text { Between } \\
2-8 \text { weeks }\end{array}$ \\
\hline Cryptococcosis & \multicolumn{3}{|c|}{ Between 4-6 weeks } \\
\hline $\begin{array}{l}\text { Pneumocystis } \\
\text { pneumonia }\end{array}$ & \multirow{2}{*}{\multicolumn{3}{|c|}{ Between 2-4 weeks }} \\
\hline $\begin{array}{l}\text { Mycobacterium avium } \\
\text { complex infection }\end{array}$ & & & \\
\hline \multicolumn{4}{|l|}{ Others } \\
\hline $\begin{array}{l}\text { Cytomegalovirus } \\
\text { infection }\end{array}$ & \multirow{2}{*}{\multicolumn{3}{|c|}{ As soon as possible }} \\
\hline $\begin{array}{l}\text { Progressive multifocal } \\
\text { leukoencephalopathy }\end{array}$ & & & \\
\hline $\begin{array}{l}\text { Cryptosporidium } \\
\text { infection }\end{array}$ & & & \\
\hline
\end{tabular}

*More severe clinical disease was defined as low Karnofsky score, low body mass index [BMI], low hemoglobin, low albumin, organ system dysfunction, or extent of disease. evidence in support of either early or late initiation of ART to date. Nevertheless, it is recommended that ART initiation should be delayed until 4-6 weeks after initiation of fungal treatment as shown in Table 2. Previous studies showed that $8 \%-50 \%$ of AIDS patients with cryptococcosis developed cryptococcal IRIS after initiation of ART [34-36]. Therefore, IRIS should be vigorously managed if ART is initiated earlier.

\section{Pneumocystis pneumonitis}

With regard to Pneumocystis pneumonitis, a randomized control trial demonstrated lower rate of mortality and disease progression in the patients who received early ART at a median of 12 days after treatment of opportunistic infection. All most one-third of the patients enrolled into this study were diagnosed Pneumocystis pneumonitis [31]. However, severe IRIS has been reported [37]. Thus, all patients should be carefully monitored after the first few weeks of ART initiation. It is recommended to start ART between 2-4 weeks after starting treatment for Pneumocystis pneumonitis. Recommendations for ART initiation in patients with Pneumocystis pneumonitis and other opportunistic infections are shown in Table 2. All HIV-infected patients with moderate-to-severe Pneumocystis pneumonitis, defined by room air $\mathrm{pO}_{2}<70 \mathrm{~mm} \mathrm{Hg}$ or alveolar-arterial $\mathrm{O}_{2}$ gradient $\geq 35 \mathrm{~mm} \mathrm{Hg}$, should receive adjunctive corticosteroids combined with specific therapy [38].

\section{Recommended initial ART regimens in antiretroviral naïve HIV-infected patients}

Optimal initial ART regimens for antiretroviral naïve HIV-infected patients should consist of two nucleoside reverse-transcriptase inhibitors (NRTIs) plus the third antiretrovirals. The NNRTIs are potent but have the limitation of a low genetic barrier to drug resistance that requires only a single mutation to confer high level of drug resistance except etravirine [39]. Nonetheless, due to its proven long-term efficacy in various large scale trials, its availability, less drug-drug interaction and its low cost [40], the guidelines recommend to use non-nucleoside reverse-transcriptase inhibitor (NNRTI) as the third agent in combination to 2 NRTIs. A fixed-dose combination is preferred. The current guidelines still emphasized on avoidance of $\mathrm{d} 4 \mathrm{~T}$ as a preferred option because of its risk of mitochondrial toxicity [41], and should consider switching to another NRTI in currently treated patients.

Efavirenz-based ART has been extensively used worldwide for more than a decade and it has shown durability in treatment-naive patients $[40,42-45]$. This regimen has comparable or superior virologic responses to all current available drugs in the country and this drug showed consistent virologic responses across any plasma HIV levels and CD4 counts [46]. In addition, efavirenz-based ART 
regimen can be given once daily and is co-formulated with tenofovir and emtricitabine. Thus, efavirenz is recommended as the third drug combined with NRTI backbone. If the patients cannot tolerate efavirenz due to neuropsychiatric adverse events and others, the next NNRTI option is either rilpivirine or nevirapine. The pooled results of ECHO and THRIVE demonstrated that the proportion of patients with viral suppression at 48 weeks was comparable in the rilpivirine and efavirenz-containing arms [47]. Rilpivirine was well tolerated. However, a higher rate of HIV resistanceassociated mutations among patients with a baseline HIV viral load $>100,000$ copies $/ \mathrm{mL}$, the risk of virologic failure was higher in the rilpivirine arm compared with the efavirenz arm $[48,49]$. Plasma HIV RNA should be measured prior to starting rilpivirine and this drug is not recommended in the patients with baseline HIV viral load $>100,000$ copies/mL. In addition, patients should be well informed on 2 limitations of rilpivirine i.e., should be taken with food to optimize its absorption and should be aware of some relevant drug-drug interactions. There were no significant differences in terms of virologic or immunologic outcomes between treatment-naive patients assigned to nevirapine or efavirenz-based ART in the $2 \mathrm{NN}$ study [42]. However, a recent systematic review showed that efavirenz-based ART is significantly less likely to lead to virologic failure compared to nevirapine-based ART [50]. Nevirapine is more toxic during the first three months of therapy [42]. Therefore, nevirapine has been changed from recommended NNRTI to be an alternative to efavirenz. A dose of nevirapine $200 \mathrm{mg}$ once daily is recommended for the first 14 days prior to increasing to usual dose at $200 \mathrm{mg}$ twice daily. However, nevirapine should not be initiated in women with a baseline CD4 cell count $>250$ cells $/ \mathrm{mm}^{3}$ or in men with a CD4 cell count $>400$ cells $/ \mathrm{mm}^{3}$ because these CD4 thresholds represent major risk factors for liver toxicity. If the patients cannot tolerate all three recommended NNRTIs, the next alternative third agents are protease inhibitors, including lopinavir/ritonavir or atazanavir/ritonavir.

With regard to NRTI backbone, virologic responses were significantly higher among patients receiving tenofovir/emtricitabine compared with zidovudine/lamivudine [51]. Tenofovir in combination with emtricitabine or lamivudine is recommended as the preferred backbone. Because tenofovir, emtricitabine and lamivudine have activities against both HIV and hepatitis B virus, thus tenofovir plus emtricitabine or lamivudine is also recommended in the patients with such co-infection $[52,53]$. If tenofovir is contraindicated, the alternative NRTIs include abacavir or zidovudine. Stavudine is no longer recommended as first-line drug due to its high rate of toxicities as aforementioned. The patients who have received stavudine, regardless the development of its adverse events, should switch to tenofovir, while their plasma HIV viral load is still undetectable. Currently available antiretroviral drugs in Thailand and the recommended dosages are summarized in Table 3. Initial and alternative ART regimens in antiretroviral naïve HIVinfected patients are summarized in Table 4. In terms of antiretroviral-naïve pregnant women, more data regarding safety of efavirenz are available and it provides increased reassurance for recommending this drug [54]. Thus, efavirenz combined with tenofovir plus emtricitabine or lamivudine is recommended as a first-line therapy.

\section{Antiretroviral therapy in treatment-naive patients who co-infected with HIV and tuberculosis}

Treatment with antiretroviral drugs in patients who coinfected with HIV and tuberculosis is relatively complex. These issues include poor tolerability of concomitant treatment regimens, drug co-toxicities, polypharmacy impacts on adherence, as well as pharmacokinetic drug interactions between rifampicin and antiretroviral drugs [55,56]. A rifampicin-based anti-tuberculosis regimen is essential [57]. All patients with HIV-related tuberculosis should be treated with a rifampicin-containing regimen for the full course of tuberculosis treatment [57]. Rifampicin induces hepatic cytochrome P-450 resulting in a significant decrease of plasma NNRTI and protease inhibitor concentrations [58,59]. For patients who are receiving non-rifampicin containing anti-tuberculosis regimens, the recommended ART regimens are the same as for nontuberculosis patients. For patients who are treated with rifampicin-containing anti-tuberculosis regimen, efavirenzbased ART is recommended. The dosage of efavirenz is no longer needed adjustment by weight. Standard dose of efavirenz was efficacious in the patients who were receiving rifampicin in Thais $[60,61]$. Thus, all patients are recommended to receive the dosage of efavirenz at $600 \mathrm{mg} /$ day. A number of studies in Thailand have shown that nevirapine at a normal dose of $400 \mathrm{mg} /$ day can be used effectively with rifampicin $[59,62,63]$. One study found that an increase of nevirapine dose to $600 \mathrm{mg}$ per day, with a lead-in of $200 \mathrm{mg}$ twice daily, was associated with a high rate of liver toxicity and is therefore not recommended [62]. Thus, a standard dose of nevirapine is an alternative to efavirenz for patients treated with rifampicin, and leadin nevirapine treatment $(200 \mathrm{mg} /$ day $)$ during the first 2 weeks is not necessary [64]. Rilpivirine is contraindicated in patients taking rifampicin. In case the patient cannot tolerate efavirenz- or nevirapine- containing ART, the other alternative drug is raltegravir at $400 \mathrm{mg}$ twice daily [65]. There is limited clinical experience with use of concomitant raltegravir and rifampicin, especially in larger and long-term trials. Thus, this regimen should be prescribed with caution. 
Table 3 Current available antiretroviral drugs in Thailand

\begin{tabular}{|c|c|c|c|}
\hline Generic Name & Abbreviation & Dosage form & Adult dose \\
\hline \multicolumn{4}{|c|}{ Nucleoside reverse transcriptase inhibitors (NRTIs) } \\
\hline Lamivudine & $3 T C$ & $150,300 \mathrm{mg}, 10 \mathrm{mg} / \mathrm{ml}$ & 150 mg q 12 h or 300 mg OD \\
\hline Abacavir & ABV & 300 mg & $300 \mathrm{mg}$ q $12 \mathrm{~h}$ or $600 \mathrm{mg}$ OD \\
\hline Zidovudine & AZT & $100,300 \mathrm{mg}, 10 \mathrm{mg} / \mathrm{ml}$ & $200-300 \mathrm{mg} \mathrm{q} 12 \mathrm{~h}$ \\
\hline \multirow[t]{2}{*}{ Stavudine } & $d 4 \mathrm{~T}$ & $15,20,30 \mathrm{mg}$ & $30 \mathrm{mg} \mathrm{q} 12 \mathrm{~h}$ \\
\hline & & $5 \mathrm{mg} / \mathrm{ml}$ & \\
\hline \multirow[t]{2}{*}{ Didanosine } & $\mathrm{DDI}$ & 250, 400 mg (extended release capsule) & $\leq 60 \mathrm{~kg} 250 \mathrm{mg} \mathrm{OD},>60 \mathrm{~kg} 400 \mathrm{mg} \mathrm{OD}$ \\
\hline & & $25,125,200 \mathrm{mg}$ (Buffer tablet) & $\begin{array}{l}\text { with TDF } \leq 60 \mathrm{~kg} 200 \mathrm{mg} \mathrm{OD},>60 \mathrm{~kg} \\
250 \mathrm{mg} \text { OD on empty stomach }\end{array}$ \\
\hline Tenofovir & TDF & $300 \mathrm{mg}$ & 1 tab OD \\
\hline \multicolumn{4}{|l|}{ Combined NRTIs } \\
\hline Zidovudine + Lamivudine & $\mathrm{AZTT} / 3 \mathrm{TC}$ & $300 / 150 \mathrm{mg}$ & 1 tab q $12 \mathrm{~h}$ \\
\hline Abacavir + Lamivudine & ABV/3TC & $600 / 300 \mathrm{mg}$ & 1 tab OD \\
\hline Tenofovir + Emtricitabine & TDF/FTC & $300 / 200 \mathrm{mg}$ & 1 tab OD \\
\hline Stavudine + Lamivudine & $\mathrm{D} 4 \mathrm{~T} / 3 \mathrm{TC}$ & $30 / 150 \mathrm{mg}$ & 1 tab q $12 \mathrm{~h}$ \\
\hline \multicolumn{4}{|c|}{ Non-Nucleoside reverse transcriptase inhibitors (NNRTIs) } \\
\hline Rilpivirine & RPV & $25 \mathrm{mg}$ & 1 tab OD with meal \\
\hline Efavirenz & EFV & $50,200,600 \mathrm{mg}$ & $\begin{array}{l}600 \mathrm{mg} \mathrm{OD} \text { hs, on empty stomach to } \\
\text { reduce side effect }\end{array}$ \\
\hline Etravirine & ETR & $100 \mathrm{mg}$ & 2 tab q $12 \mathrm{~h}$ with meal \\
\hline Nevirapine & NVP & $200 \mathrm{mg}, 10 \mathrm{mg} / \mathrm{ml}$ & $200 \mathrm{mg}$ q $12 \mathrm{~h}$ or $400 \mathrm{mg}$ OD \\
\hline \multicolumn{4}{|l|}{ Combine NRTIs + NNRTIs } \\
\hline Tenofovir + Emtricitabine + Efavirenz & TDF/FTC/EFV & $300 / 200 / 600 \mathrm{mg}$ & $\begin{array}{l}1 \text { tab OD hs, on empty stomach } \\
\text { to reduce side effect }\end{array}$ \\
\hline Stavudine + Lamivudine + Nevirapine & GPO vir S & $30 / 150 / 200 \mathrm{mg}$ & 1 tab q $12 \mathrm{~h}$ \\
\hline Zidovudine + Lamivudine + Nevirapine & GPO vir Z 250 & $250 / 150 / 200 \mathrm{mg}$ & 1 tab q $12 \mathrm{~h}$ \\
\hline \multicolumn{4}{|l|}{ Protease inhibitors (PIs) } \\
\hline \multirow[t]{2}{*}{ Atazanavir } & ATV & $200,300 \mathrm{mg}$ & $\begin{array}{l}300 \text { mg OD (boosted rtv), } 400 \text { mg OD, } \\
\text { with TDF } 300 \text { mg OD (boosted rtv) } \\
\text { with EFV }\end{array}$ \\
\hline & & & 400 mg (boosted rtv), with meal \\
\hline Darunavir & DRV & $300,600 \mathrm{mg}$ & 600 mg q 12 h, 800 mg OD with meal \\
\hline Indinavir & IDV & $200,400 \mathrm{mg}$ & $800 \mathrm{mg} \mathrm{q} 12 \mathrm{~h}$ \\
\hline Lopinavir/ritonavir & LPV/rtv & $100 / 25,200 / 50 \mathrm{mg}, 80 / 20 \mathrm{mg} / \mathrm{ml}$ & $400 / 100 \mathrm{mg} \mathrm{q} 12 \mathrm{~h}$ or $800 / 200 \mathrm{mg}$ OD \\
\hline Ritonavir & RTV & $100 \mathrm{mg}$ & boosted RTV 100 mg q12 h or OD \\
\hline Saquinavir & SQV & $500 \mathrm{mg}$ & $2 \mathrm{tab} q 12 \mathrm{~h}$ \\
\hline \multicolumn{4}{|l|}{ CCR5 Inhibitor (CCR5I) } \\
\hline \multirow[t]{3}{*}{ Maraviroc } & MRV & $150,300 \mathrm{mg}$ & $\begin{array}{l}150 \mathrm{mg} \text { q } 12 \mathrm{~h} \text { with strong cyp } 3 \mathrm{~A} \text { inh. } \\
\text { (with or without } 3 \mathrm{~A} \text { ind.) ex. Pls except TPV/r }\end{array}$ \\
\hline & & & $\begin{array}{l}300 \mathrm{mg} \text { q } 12 \mathrm{~h} \text { with NRTIs, T20, NVP, RAL, } \\
\text { TPV/r and other drug that not strong } \\
3 \mathrm{~A} \text { inh./ind. }\end{array}$ \\
\hline & & & $\begin{array}{l}600 \mathrm{mg} \text { q } 12 \mathrm{~h} \text { with cyp } 3 \mathrm{~A} \text { ind ex. EFV, } \\
\text { ETR (without } 3 \mathrm{~A} \text { inh.) }\end{array}$ \\
\hline \multicolumn{4}{|l|}{ Integrase inhibitors } \\
\hline Raltegravir 400 mg & RAL & $400 \mathrm{mg}$ & 1 tab q 12 h \\
\hline
\end{tabular}


Table 4 Initial and alternative antiretroviral therapy regimens in antiretroviral naïve HIV-infected patients

\begin{tabular}{|c|c|c|c|c|}
\hline NRTI backbones & & NNRTIs & & Other third drugs \\
\hline Recommended drugs & & Recommended drug & & Recommended drug \\
\hline Tenofovir/emtricitabine & plus & Efavirenz & In case the patients cannot tolerate NNRTIs & Lopinavir/ritonavir \\
\hline Tenofovir/lamivudine & & & & Atazanavir/ritonavir \\
\hline Alternative drugs & & Alternative drugs & & \\
\hline Abacavir + lamivudine & & Rilpivirine & & \\
\hline Zidovudine + lamivudine & & Nevirapine & & \\
\hline
\end{tabular}

$\mathrm{NRTI}=$ Nucleoside reverse transcriptase inhibitor.

NNRTIs = Non-nucleoside reverse transcriptase inhibitors.

\section{Laboratory monitoring of antiretroviral therapy}

Recommendations on the CD4 cell count, plasma HIV viral load monitoring, and other relevant laboratory tests are summarized in Table 5. HIV viral load and CD4 cell count are key surrogate markers of HIV treatment response before and after ART initiation, respectively [7]. Decreases in plasma HIV viral load following ART initiation are associated with reduced risk of progression to AIDS or death. This guideline recommends to monitor plasma HIV viral load regularly at 3 months and 6 months in the first year of ART and at least yearly afterward. With regard to immunologic response, CD4 cell count should be monitored at 6 months and 12 months in the first year and until CD4 cell count $>350$ cells $/ \mathrm{mm}^{3}$ and viral load $<50$ copies/mL. HIV genotypic drug-resistance testing is recommended to guide treatment choices after virological failure. This test should be performed in case of plasma HIV viral load $>1,000$ copies $/ \mathrm{mL}$ and it should be performed while the patient is taking antiretroviral drugs or within 1 month after discontinuing ART.

Antiretroviral therapy in treatment-experienced patients New drugs that have new mechanisms of action and activity against drug-resistant viruses have been added in the guidelines. Based on current available drugs in the country, the ultimate goal to treat treatment-experienced patients is to re-achieve virologic suppression to $<50$ copies/mL [66]. Thus, a careful review of the previous antiretroviral history, all previous $\mathrm{HIV}-1$ genotypic resistance test results, potential drug-drug interactions, relevant co-morbidities, antiretroviral drug availability, and a patient's adherence is important to properly plan for selecting the next ART regimen.

\section{First ART regimen failure NNRTI-based first-line failure}

The SECOND-LINE and EARNEST studies recently showed that second-line regimens consisting of a boostedprotease inhibitor plus 2 NRTIs/NtRTIs and boostedprotease inhibitor plus raltegravir led to favorable treatment outcomes for patients with HIV after initial NNRTI-based regimen failure $[67,68]$. In protease inhibitor-naive patients failing NNRTI-based first-line ART, mono-therapy with ritonavir-boosted lopinavir had a significantly lower proportion of patients with undetectable viral load compared to the ritonavir-boosted lopinavir plus tenofovir and lamivudine [69]. Thus, ritonavir-boosted lopinavir monotherapy is not recommended as a second-line option. Antiretroviral treatment options after first-line NNRTI-based regimens are summarized in Table 6.

Table 5 Recommendations on the CD4 cell count, HIV viral monitoring, and other tests

\begin{tabular}{llll}
\hline Laboratory testing & At entry into care & First year of ART & After first year \\
\hline CD4 cell count & At entry & At 6 and 12 months & At 6 and 12 months until CD4 count $>350$ cells $/ \mathrm{mm}^{3}$ \\
with viral load $<50$ copies $/ \mathrm{ml}^{\text {and once a year afterward. }}$ \\
Plasma HIV viral load & - & At 3 and 6 months & Every 12 months if viral load $<50$ copies $/ \mathrm{ml}$ \\
HBsAg & At entry & - & - \\
Anti-HCV & At entry & - & - \\
VDRL & At entry & - & - \\
ALT & At entry & If indicated & At entry \\
Creatinine & At entry & At 6 and 12 months & Every 12 months or if indicated \\
Total cholesterol & High risk group & Every 12 months or if indicated & Every 12 months or if indicated \\
Fasting blood sugar & High risk group & Every 12 months or if indicated & Every 12 months or if indicated \\
Urinalysis & At entry & Every 12 months or if indicated & Every 12 months or if indicated \\
\hline
\end{tabular}


Table 6 Antiretroviral options after first-line non-nucleoside reverse transcriptase inhibitor-based regimens

\begin{tabular}{lll}
\hline NRTI in failing regimen & NRTI option in next regimen & Third agent \\
\hline Tenofovir & Choosing NRTI based on genotypic resistant result & Recommended agent: lopinavir/ritonavir \\
& or considering zidovudine plus lamivudine & Alternative agents: Atazanavir/ritonavir \\
& & Darunavir/ritonavir \\
Raltegravir* & Dolutegravir \\
Zidovudine, stavudine or abacavir & Choosing NRTI based on genotypic resistant result & or considering tenofovir plus lamivudine or emtricitabine
\end{tabular}

*Used with caution in non-fully active NRTI backbone owing to rapid emerging of treatment failure.

$\mathrm{NRTI}=$ Nucleoside reverse transcriptase inhibitor.

\section{Boosted-protease inhibitor based first-line failure}

In patients failing an initial protease inhibitor-based regimen, NRTI resistance mutations are commonly observed and protease inhibitor resistance-associated mutations are rare. Nevertheless, protease inhibitor resistance-associated mutations are accumulated in patients with late detection of virologic failure. Choosing a new protease inhibitor in the new regimen is based on the number and patterns of protease inhibitor resistance mutations [39]. An active protease inhibitor, boosted with ritonavir, should be used as a second regimen combined with the two other active drugs, either NRTI or NNRTI, as indicated by the genotypic resistance test results.

\section{Multiclass ARV failure}

In case of multi-class failure, the subsequent regimen should be consisted of new three fully active drugs, including integrase inhibitors (raltegravir or dolutegravir), protease inhibitors (daurunavir/ritonavir), NNRTIs (etravirine or rilpivirine), and CCR5 inhibitors (maraviroc) based on the genotypic resistance test results. If this is not possible, at least two active drugs are required or expert consultation is advised. The challenge is, however, not all listed new ARVs are available and accessible in Thailand.

\section{Conclusions}

The 2014 HIV treatment guidelines provide the key updated data regarding when to commence antiretroviral treatment, optimal treatment regimens, the management of HIV co-infection with opportunistic infections, treatment monitoring, as well as the management of ART failure. However, the guidelines are not able to provide guidance on care to cover all patients' circumstances. Thus clinicians should make proper decision on the basis of their patient circumstances. Of note, the success of life-long antiretroviral therapy is critically depended on the attitude, the knowledge, the skill of the health care providers, but more important the commitment of the patients through the good relationship and support from the health care providers.

\section{Competing interests}

Kiat Ruxurngtham (KR) has been served as a consultant for Merck, Tibotec and Mylan. He has had paid speaking engagements with Bristol-Meyers Squibb, Merck, Roche, Jensen-Cilag, GlaxoSmithKline, Thai GPO, and Mylan Lab limited. KR has also received a support from the Senior Researcher Scholar, the Thailand Research Fund (TRF).

\section{Authors' contributions}

WM, SO, SB, ML, KR, PP, NH, WR, PC, WT, SK, AA, AS and TA reviewed and drafted manuscript. All authors read and approved the final manuscript.

\section{Acknowledgements}

The Adults and Adolescents Committee of the Thai National HIV Guidelines Working Group acknowledges the following participants in formulating these guidelines: Surapol Suwanagool, Praphan Phanuphak, Manoon Leechawengwongs, Narin Hiransuthikul, Thanomsak Anekthananon, Kiat Ruxrungtham, Winai Ratanasuwan, Wichai Techasathit, Ploenchan Chetchotisakd, Weerawat Manosuthi, Opas Putcharoen, Woraphot Tantisiriwat, Chureerat Bowonwatanwong, Tavatchai Jariyasethpong, Piroon Mootsikapun, Somnuek Sungkanuparph, Sasisopin Kiertiburanakul, Anchalee Avihingsanon, Somsit Tansuphaswadikul, Wisit Prasithsirikul, Kulkanya Chokephaibulkit, Kitti Trakulhoon, Sorakij Bhakeecheep, Sumet Ongwandee, Anucha Apisarnthanarak, Rangsima Lolekha, Thana Khawcharoenporn, Peerawong Werarak.

\section{Author details}

'Department of Medicine, Bamrasnaradura Infectious Diseases Institute, Ministry of Public Health, Tiwanon Road, Nonthaburi 11000, Thailand. ${ }^{2}$ Bureau of AIDS, TB, and STIS, Department of Disease Control, Ministry of Public Health, Nonthaburi, Thailand. ${ }^{3}$ National Health Security Office, Bangkok, Thailand. ${ }^{4}$ Thai AIDS Society, Bangkok, Thailand. ${ }^{5}$ Department of Medicine, Faculty of Medicine, Chulalongkorn University, Bangkok, Thailand. ${ }^{6}$ HIV-NAT, Thai Red Cross AIDS Research Centre, Bangkok, Thailand. ${ }^{7}$ Faculty of Medicine Siriraj Hospital, Mahidol University, Bangkok, Thailand. ${ }^{8}$ Faculty of Medicine, Khon Kaen University, Khon Kaen, Thailand. ${ }^{9}$ Department of Preventive Medicine, Faculty of Medicine Srinakharinwirot University, Nakornnayok, Thailand. ${ }^{10}$ Faculty of Medicine Ramathibodi Hospital, Mahidol University, Bangkok, Thailand. " $T$ Thailand Ministry of Public Health-U.S. CDC Collaboration (TUC), Nonthaburi, Thailand.

Received: 26 November 2014 Accepted: 8 April 2015

Published online: 24 April 2015

\section{References}

1. Anekthananon T, Ratanasuwan W, Techasathit W, Sonjai A, Suwanagool S. Safety and efficacy of a simplified fixed-dose combination of stavudine, lamivudine and nevirapine (GPO-VIR) for the treatment of advanced HIV-infected patients: a 24-week study. J Med Assoc Thai. 2004;87(7):760-7.

2. Getahun A, Tansuphasawadikul S, Desakorn V, Dhitavat J, Pitisuttithum P. Efficacy and safety of generic fixed-dose combination of stavudine, lamivudine and nevirapine (GPO-vir) in advanced HIV infection. J Med Assoc Thai. 2006;89(9):1472-8 
3. Manosuthi W, Chimsuntorn S, Likanonsakul S, Sungkanuparph S. Safety and efficacy of a generic fixed-dose combination of stavudine, lamivudine and nevirapine antiretroviral therapy between HIV-infected patients with baseline CD4 $<50$ versus CD4 $>$ or $=50$ cells $/ \mathrm{mm} 3$. AIDS Res Ther. 2007:4:6

4. Kiertiburanakul S, Khongnorasat S, Rattanasiri S, Sungkanuparph S. Efficacy of a generic fixed-dose combination of stavudine, lamivudine and nevirapine (GPO-VIR) in Thai HIV-infected patients. J Med Assoc Thai. 2007:90(2):237-43.

5. Sungkanuparph S, Techasathit W, Utaipiboon C, Chasombat S, Bhakeecheep $\mathrm{S}$, Leechawengwong $\mathrm{M}$, et al. Thai national guidelines for antiretroviral therapy in HIV-1 infected adults and adolescents 2010. Asian Biomedicine. 2010;4:515-28.

6. Organization WH. Consolidated guidelines on the use of antiretroviral drugs for treating and preventing HIV infection. Recommendations for a public health approach. 2013. http://www.who.int/hiv/pub/guidelines/arv2013/ download/en/

7. Gunthard HF, Aberg JA, Eron JJ, Hoy JF, Telenti A, Benson CA, et al. Antiretroviral treatment of adult HIV infection: 2014 recommendations of the International Antiviral Society-USA Panel. Jama. 2014;312(4):410-25.

8. Panel on Antiretroviral Guidelines for Adults and Adolescents. Guidelines for the use of antiretroviral agents in HIV-1-infected adults and adolescents. Department of Health and Human Services. Available at http:/aidsinfo.nih.gov/ContentFiles/Adultand AdolescentGL.pdf. Accessed 10 November 2015.

9. Hogg RS, Yip B, Chan KJ, Wood E, Craib KJ, O'Shaughnessy MV, et al. Rates of disease progression by baseline CD4 cell count and viral load after initiating triple-drug therapy. Jama. 2001;286(20):2568-77.

10. Kitahata MM, Gange SJ, Abraham AG, Merriman B, Saag MS, Justice AC, et al. Effect of early versus deferred antiretroviral therapy for HIV on survival. N Engl J Med. 2009;360(18):1815-26.

11. Collaboration H-C, Cain LE, Logan R, Robins JM, Sterne JA, Sabin C, et al. When to initiate combined antiretroviral therapy to reduce mortality and AIDS-defining illness in HIV-infected persons in developed countries: an observational study. Ann Intern Med. 2011;154(8):509-15.

12. Writing Committee for the CC. Timing of HAART initiation and clinical outcomes in human immunodeficiency virus type 1 seroconverters. Arch Intern Med. 2011:171(17):1560-9.

13. Strategies for Management of Antiretroviral Therapy Study G, Emery S, Neuhaus JA, Phillips AN, Babiker A, Cohen CJ, et al. Major clinical outcomes in antiretroviral therapy (ART)-naive participants and in those not receiving ART at baseline in the SMART study. J Infect Dis. 2008;197(8):1133-44.

14. Chaiwarith $R$, Salee $P$, Kotarathitithum W, Sirisanthana T, Supparatpinyo K. Long-term CD4 cell count recovery among Thai naive HIV-infected patients initiating HAART at low CD4 cell count. Curr HIV Res. 2009;7(3):340-5.

15. When To Start C, Sterne JA, May M, Costagliola D, de Wolf F, Phillips AN, et al. Timing of initiation of antiretroviral therapy in AIDS-free HIV-1-infected patients: a collaborative analysis of 18 HIV cohort studies. Lancet. 2009;373(9672):1352-63.

16. Grinsztejn B, Hosseinipour MC, Ribaudo HJ, Swindells S, Eron J Chen $Y Q$, et al. Effects of early versus delayed initiation of antiretrovira treatment on clinical outcomes of HIV-1 infection: results from the phase 3 HPTN 052 randomised controlled trial. Lancet Infect Dis. 2014;14(4):281-90

17. loannidis JP, Abrams EJ, Ammann A, Bulterys M, Goedert JJ, Gray L, et al. Perinatal transmission of human immunodeficiency virus type 1 by pregnant women with RNA virus loads $<1000$ copies/ml. J Infect Dis. 2001;183(4):539-45

18. Mofenson LM, Lambert JS, Stiehm ER, Bethel J, 3rd Meyer WA, Whitehouse J, et al. Risk factors for perinatal transmission of human immunodeficiency virus type 1 in women treated with zidovudine. Pediatric AIDS clinical trials group study 185 team. N Engl J Med. 1999;341(6):385-93.

19. Manosuthi W, Mankatitham W, Lueangniyomkul A, Thongyen S, Likanonsakul S, Suwanvattana $P$, et al. Time to initiate antiretroviral therapy between 4 weeks and 12 weeks of tuberculosis treatment in HIV-infected patients: results from the TIME study. J Acquir Immune Defic Syndr. 2012:60(4):377-83

20. Manosuthi W, Chottanapand S, Thongyen S, Chaovavanich A, Sungkanuparph S. Survival rate and risk factors of mortality among HIV/ tuberculosis-coinfected patients with and without antiretroviral therapy. J Acquir Immune Defic Syndr. 2006;43(1):42-6.
21. Sungkanuparph S, Manosuthi W, Kiertiburanakul S, Vibhagool A. Initiation of antiretroviral therapy in advanced AIDS with active tuberculosis: clinical experiences from Thailand. J Infect. 2006;52(3):188-94.

22. Akksilp S, Karnkawinpong O, Wattanaamornkiat W, Viriyakitja D, Monkongdee P, Sitti W, et al. Antiretroviral therapy during tuberculosis treatment and marked reduction in death rate of HIV-infected patients, Thailand. Emerg Infect Dis. 2007;13(7):1001-7.

23. Abdool Karim SS, Naidoo K, Grobler A, Padayatchi N, Baxter C, Gray A, et al. Timing of initiation of antiretroviral drugs during tuberculosis therapy. N Engl J Med. 2010;362(8):697-706.

24. Blanc FX, Sok T, Laureillard D, Borand L, Rekacewicz C, Nerrienet E, et al. Earlier versus later start of antiretroviral therapy in HIV-infected adults with tuberculosis. N Engl J Med. 2011;365(16):1471-81.

25. Torok ME, Yen NT, Chau TT, Mai NT, Phu NH, Mai PP, et al. Timing of initiation of antiretroviral therapy in human immunodeficiency virus (HIV)-associated tuberculous meningitis. Clini Infect Dis: an official Publ Infect Dis Soc Am. 2011:52(11):1374-83.

26. Mfinanga SG, Kirenga BJ, Chanda DM, Mutayoba B, Mthiyane T, Yimer G, et al. Early versus delayed initiation of highly active antiretroviral therapy for HIV-positive adults with newly diagnosed pulmonary tuberculosis (TB-HAART): a prospective, international, randomised, placebo-controlled trial. Lancet Infect Dis. 2014;14(7):563-71.

27. Havlir DV, Kendall MA, Ive P, Kumwenda J, Swindells S, Qasba SS, et al. Timing of antiretroviral therapy for HIV-1 infection and tuberculosis. N Engl J Med. 2011;365(16):1482-91

28. Jongwutiwes $U$, Sungkanuparph S, Kiertiburanakul S. Comparison of clinical features and survival between cryptococcosis in human immunodeficiency virus (HIV)-positive and HIV-negative patients. Jpn J Infect Dis. 2008;61(2):111-5.

29. Manosuthi W, Chottanapund S, Sungkanuparph S. Mortality rate of early versus deferred initiation of antiretroviral therapy in HIV-1-infected patients with cryptococcal meningitis. J Acquir Immune Defic Syndr. 2008;48(4):508-9.

30. Chottanapund S, Singhasivanon P, Kaewkungwal J, Chamroonswasdi K Manosuthi W. Survival time of HIV-infected patients with cryptococcal meningitis. J Med Assoc Thail = Chotmaihet thangphaet. 2007;90(10):2104-11.

31. Zolopa A, Andersen J, Powderly W, Sanchez A, Sanne I, Suckow C, et al. Early antiretroviral therapy reduces AIDS progression/death in individuals with acute opportunistic infections: a multicenter randomized strategy trial. PLoS One. 2009:4(5):e5575.

32. Makadzange AT, Ndhlovu CE, Takarinda K, Reid M, Kurangwa M, Gona P et al. Early versus delayed initiation of antiretroviral therapy for concurrent HIV infection and cryptococcal meningitis in sub-saharan Africa. Clin Infect Dis: an official Publ Infect Dis Soc Am. 2010;50(11):1532-8.

33. Njei B, Kongnyuy EJ, Kumar S, Okwen MP, Sankar MJ, Mbuagbaw L. Optimal timing for antiretroviral therapy initiation in patients with HIV infection and concurrent cryptococcal meningitis. Cochrane Database Syst Rev. 2013:2:CD009012.

34. Jenny-Avital ER, Abadi M. Immune reconstitution cryptococcosis after initiation of successful highly active antiretroviral therapy. Clin Infect Dis: an official Publ Infect Dis Soc Am. 2002;35(12):e128-33.

35. Lortholary O, Fontanet A, Memain N, Martin A, Sitbon K, Dromer F, et al. Incidence and risk factors of immune reconstitution inflammatory syndrome complicating HIV-associated cryptococcosis in France. Aids. 2005;19(10):1043-9.

36. Shelburne 3rd SA, Darcourt J, White Jr AC, Greenberg SB, Hamill RJ, Atmar $\mathrm{RL}$, et al. The role of immune reconstitution inflammatory syndrome in AIDS-related Cryptococcus neoformans disease in the era of highly active antiretroviral therapy. Clin Infect Dis: an official Publ Infect Dis Soc Am. 2005;40(7):1049-52.

37. Jagannathan $P$, Davis $E_{1}$ Jacobson $M$, Huang L. Life-threatening immune reconstitution inflammatory syndrome after Pneumocystis pneumonia: a cautionary case series. Aids. 2009:23(13):1794-6.

38. Briel M, Bucher HC, Boscacci R, Furrer H. Adjunctive corticosteroids for Pneumocystis jiroveci pneumonia in patients with HIV-infection. Cochrane Database Syst Rev. 2006;3:CD006150.

39. Wensing AM, Calvez V, Gunthard HF, Johnson VA, Paredes R, Pillay D, et al. 2014 Update of the drug resistance mutations in HIV-1. Topics in antiviral medicine. 2014;22(3):642-50. 
40. Riddler SA, Haubrich R, DiRienzo AG, Peeples L, Powderly WG, Klingman KL, et al. Class-sparing regimens for initial treatment of HIV-1 infection. N Engl J Med. 2008;358(20):2095-106.

41. Manosuthi W, Prasithsirikul W, Chumpathat N, Suntisuklappon B, Athichathanabadi C, Chimsuntorn S, et al. Risk factors for mortality in symptomatic hyperlactatemia among HIV-infected patients receiving antiretroviral therapy in a resource-limited setting. IJID: official Publ Int Soc Infect Dis. 2008;12(6):582-6.

42. van Leth F, Phanuphak P, Ruxrungtham K, Baraldi E, Miller S, Gazzard B, et al. Comparison of first-line antiretroviral therapy with regimens including nevirapine, efavirenz, or both drugs, plus stavudine and lamivudine: a randomised open-label trial, the 2NN Study. Lancet. 2004;363(9417):1253-63.

43. Squires K, Lazzarin A, Gatell JM, Powderly WG, Pokrovskiy V, Delfraissy JF, et al. Comparison of once-daily atazanavir with efavirenz, each in combination with fixed-dose zidovudine and lamivudine, as initial therapy for patients infected with HIV. J Acquir Immune Defic Syndr. 2004:36(5):1011-9.

44. Daar ES, Tierney C, Fischl MA, Sax PE, Mollan K, Budhathoki C, et al. Atazanavir plus ritonavir or efavirenz as part of a 3-drug regimen for initial treatment of HIV-1. Ann Intern Med. 2011;154(7):445-56.

45. Cohen CJ, Molina JM, Cassetti I, Chetchotisakd P, Lazzarin A, Orkin C, et al. Week 96 efficacy and safety of rilpivirine in treatment-naive, HIV-1 patients in two Phase III randomized trials. Aids. 2013;27(6):939-50.

46. Ribaudo HJ, Kuritzkes DR, Lalama CM, Schouten JT, Schackman BR, Acosta EP, et al. Efavirenz-based regimens in treatment-naive patients with a range of pretreatment HIV-1 RNA levels and CD4 cell counts. J Infect Dis. 2008:197(7):1006-10.

47. Cohen CJ, Molina JM, Cahn P, Clotet B, Fourie J, Grinsztejn B, et al. Efficacy and safety of rilpivirine (TMC278) versus efavirenz at 48 weeks in treatment-naive HIV-1-infected patients: pooled results from the phase 3 double-blind randomized ECHO and THRIVE Trials. J Acquir Immune Defic Syndr. 2012;60(1):33-42.

48. Molina JM, Cahn P, Grinsztejn B, Lazzarin A, Mills A, Saag M, et al. Rilpivirine versus efavirenz with tenofovir and emtricitabine in treatment-naive adults infected with HIV-1 (ECHO): a phase 3 randomised double-blind active-controlled trial. Lancet. 2011;378(9787):238-46.

49. Cohen CJ, Andrade-Villanueva J, Clotet B, Fourie J, Johnson MA, Ruxrungtham K, et al. Rilpivirine versus efavirenz with two background nucleoside or nucleotide reverse transcriptase inhibitors in treatment-naive adults infected with HIV-1 (THRIVE): a phase 3, randomised, non-inferiority trial. Lancet. 2011;378(9787):229-37.

50. Pillay P, Ford N, Shubber Z, Ferrand RA. Outcomes for efavirenz versus nevirapine-containing regimens for treatment of HIV-1 infection: a systematic review and meta-analysis. PLoS One. 2013;8(7):e68995.

51. Gallant JE, DeJesus E, Arribas JR, Pozniak AL, Gazzard B, Campo RE, et al. Tenofovir DF, emtricitabine, and efavirenz vs. zidovudine, lamivudine, and efavirenz for HIV. N Engl J Med. 2006;354(3):251-60.

52. Peters MG, Andersen J, Lynch P, Liu T, Alston-Smith B, Brosgart CL, et al. Randomized controlled study of tenofovir and adefovir in chronic hepatitis $B$ virus and HIV infection: ACTG A5127. Hepatology. 2006;44(5):1110-6.

53. Matthews GV, Seaberg E, Dore GJ, Bowden S, Lewin SR, Sasadeusz J, et al. Combination HBV therapy is linked to greater HBV DNA suppression in a cohort of lamivudine-experienced HIV/HBV coinfected individuals. Aids. 2009:23(13):1707-15.

54. Ford N, Mofenson L, Shubber Z, Calmy A, Andrieux-Meyer I, Vitoria M, et al Safety of efavirenz in the first trimester of pregnancy: an updated systematic review and meta-analysis. AIDS. 2014;28 Suppl 2:S123-31.

55. Cohen K, Meintjes G. Management of individuals requiring antiretroviral therapy and TB treatment. Curr Opin HIV AIDS. 2010;5(1):61-9

56. Lawn SD, Torok ME, Wood R. Optimum time to start antiretroviral therapy during HIV-associated opportunistic infections. Curr Opin Infect Dis. 2011:24(1):34-42.

57. Ahmad Khan F, Minion J, Al-Motairi A, Benedetti A, Harries AD, Menzies D. An updated systematic review and meta-analysis on the treatment of active tuberculosis in patients with HIV infection. Clin Infect Dis: an official Publ Infect Dis Soc Am. 2012;55(8):1154-63.

58. Manosuthi W, Sungkanuparph S, Thakkinstian A, Vibhagool A, Kiertiburanakul S, Rattanasiri S, et al. Efavirenz levels and 24-week efficacy in HIV-infected patients with tuberculosis receiving highly active antiretroviral therapy and rifampicin. Aids. 2005;19(14):1481-6.
59. Manosuthi W, Sungkanuparph S, Thakkinstian A, Rattanasiri S, Chaovavanich A, Prasithsirikul W, et al. Plasma nevirapine levels and 24-week efficacy in HIV-infected patients receiving nevirapine-based highly active antiretroviral therapy with or without rifampicin. Clin Infect Dis: an official Publ Infect Dis Soc Am. 2006;43(2):253-5.

60. Manosuthi W, Kiertiburanakul S, Sungkanuparph S, Ruxrungtham K, Vibhagool A, Rattanasiri S, et al. Efavirenz 600 mg/day versus efavirenz 800 $\mathrm{mg} /$ day in HIV-infected patients with tuberculosis receiving rifampicin: 48 weeks results. Aids. 2006;20(1):131-2.

61. Manosuthi W, Sungkanuparph S, Tantanathip P, Lueangniyomkul A Mankatitham W, Prasithsirskul W, et al. A randomized trial comparing plasma drug concentrations and efficacies between 2 nonnucleoside reverse-transcriptase inhibitor-based regimens in HIV-infected patients receiving rifampicin: the N2R Study. Clin Infect Dis: an official Publ Infect Dis Soc Am. 2009;48(12):1752-9.

62. Avihingsanon A, Manosuthi W, Kantipong P, Chuchotaworn C, Moolphate S, Sakornjun W, et al. Pharmacokinetics and 48-week efficacy of nevirapine: $400 \mathrm{mg}$ versus $600 \mathrm{mg}$ per day in HIV-tuberculosis coinfection receiving rifampicin. Antivir Ther. 2008;13(4):529-36.

63. Manosuthi W, Ruxrungtham K, Likanonsakul S, Prasithsirikul W, Inthong $Y$, Phoorisri T, et al. Nevirapine levels after discontinuation of rifampicin therapy and 60-week efficacy of nevirapine-based antiretroviral therapy in HIV-infected patients with tuberculosis. Clin Infect Dis: an official Publ Infect Dis Soc Am. 2007:44(1):141-4.

64. Bonnet M, Bhatt N, Baudin E, Silva C, Michon C, Taburet AM, et al. Nevirapine versus efavirenz for patients co-infected with HIV and tuberculosis: a randomised non-inferiority trial. Lancet Infect Dis. 2013;13(4):303-12.

65. Grinsztejn B, De Castro N, Arnold V, Veloso VG, Morgado M, Pilotto JH, et al. Raltegravir for the treatment of patients co-infected with HIV and tuberculosis (ANRS 12180 Reflate TB): a multicentre, phase 2, non-comparative, open-label, randomised trial. Lancet Infect Dis. 2014;14(6):459-67.

66. Fagard C, Colin C, Charpentier C, Rami A, Jacomet C, Yeni $P$, et al. Long-term efficacy and safety of raltegravir, etravirine, and darunavir/ ritonavir in treatment-experienced patients: week 96 results from the ANRS 139 TRIO trial. J Acquir Immune Defic Syndr. 2012;59(5):489-93.

67. Group S-LS, Boyd MA, Kumarasamy N, Moore CL, Nwizu C, Losso MH, et al. Ritonavir-boosted lopinavir plus nucleoside or nucleotide reverse transcriptase inhibitors versus ritonavir-boosted lopinavir plus raltegravir for treatment of HIV-1 infection in adults with virological failure of a standard first-line ART regimen (SECOND-LINE): a randomised, open-label, non-inferiority study. Lancet. 2013:381(9883):2091-9.

68. Paton N, Kityo C, Hoppe A, Hakim J, Oosterhout Jv, Siika A, et al. A pragmatic randomised controlled strategy trial of three second-line treatment options for use in public health rollout programme settings: the Europe-Africa Research Network for Evaluation of Second-line Therapy (EARNEST) Trial. 7th International AIDS Society Conference on HIV Pathogenesis, Treatment and Prevention (IAS 2013). Kuala Lumpur, June 30-July 3, 2013. Abstract WELBB02.

69. Bunupuradah T, Chetchotisakd P, Ananworanich J, Munsakul W, Jirajariyavej S, Kantipong $P$, et al. A randomized comparison of second-line lopinavir/ ritonavir monotherapy versus tenofovir/lamivudine/lopinavir/ritonavir in patients failing NNRTI regimens: the HIV STAR study. Antivir Ther. 2012;17(7):1351-61.

\section{Submit your next manuscript to BioMed Central and take full advantage of:}

- Convenient online submission

- Thorough peer review

- No space constraints or color figure charges

- Immediate publication on acceptance

- Inclusion in PubMed, CAS, Scopus and Google Scholar

- Research which is freely available for redistribution 